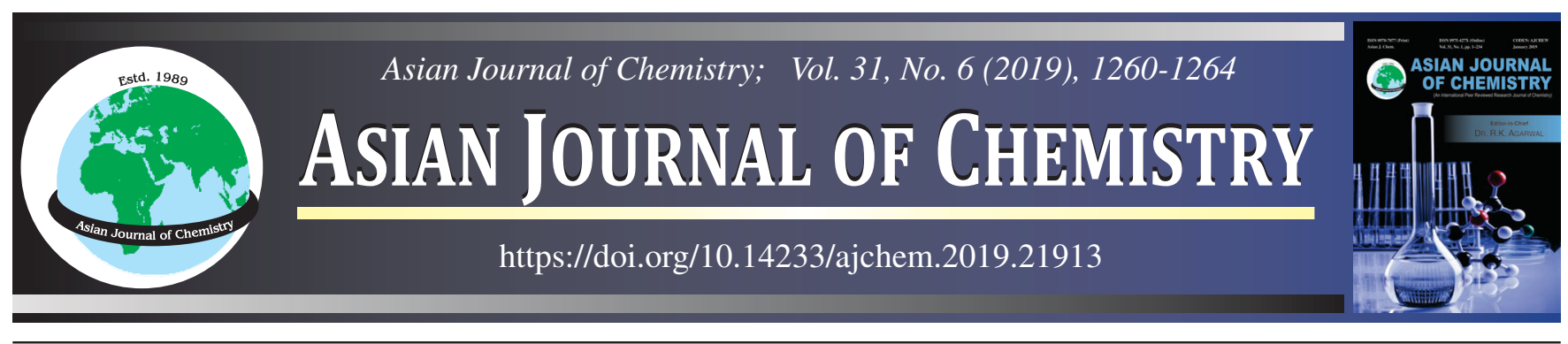

\title{
Cyclooxygenase-2 Inhibitory Compounds from the Leaves of Glycosmis pentaphylla (Retz.) A. DC.: Chemical and in silico Studies
}

\author{
Mahfuza Afroz Soma ${ }^{1}$, Mohammad Firoz Khan ${ }^{2}$, Faiza Tahia ${ }^{1}$, Md. Abdullah Al-Mansur ${ }^{3}$, \\ Mohammad Sharifur Rahman ${ }^{1}$ and Mohammad Abdur Rashid ${ }^{1, *}$
}

${ }^{1}$ Phytochemical Research Laboratory, Department of Pharmaceutical Chemistry, Faculty of Pharmacy, University of Dhaka, Dhaka-1000, Bangladesh ${ }^{2}$ Department of Pharmacy, State University of Bangladesh, Dhaka- 1205, Bangladesh

${ }^{3}$ Bangladesh Council of Scientific and Industrial Research (BCSIR), Dr. Qudrat-I-Khuda Road, Dhanmondi, Dhaka-1205, Bangladesh

*Corresponding author: E-mail: r.pchem@yahoo.com

Received: 2 January 2019;

Accepted: 3 February 2019;

Published online: 29 April 2019;

AJC-19366

Glycosmis pentaphylla is traditionally used for treating many diseases in Bangladesh. Anti-inflammatory and analgesic effects of $G l y c o s m i s$ pentaphylla have been reported prominently but no bioactive element has been identified so far. In order to explore its analgesic and antiinflammatory compound(s), phytochemical analysis was conducted. Nine compounds were isolated from the methanol extract of leaves of Glycosmis pentaphylla whose structures were solved as arborinine (1), vanillic acid (2), 3-hydroxy-4-methoxybenzoic acid (3), benzoic acid (4), p-hydroxybenzoic acid (5), stigmasterol (6), $\beta$-amyrin (7), phytol (8) and $3 \alpha, 16 \alpha$-dihydroxyolean-12-ene (9) by spectroscopic studies, including high field ${ }^{1} \mathrm{H}$ NMR analyses as well as co-TLC with authentic samples whenever possible. Among these, compounds 3 and 9 are the first report of their occurrence from $G$. pentaphylla. in silico docking studies of these metabolites with cyclooxygenase (COX)-2, an enzyme responsible for producing prostaglandins, were conducted. It was found that only arborinine and phytol can bind in the active site of $\mathrm{COX}-2$, which might be considered as the major responsible moieties to cause analgesic and anti-inflammatory activities

Keywords: Glycosmis pentaphylla, Arborinine, Phytol, COX-2, Docking, Anti-inflammatory.

\section{INTRODUCTION}

Bangladesh being in sub-tropical zone becomes a great reservoir of thousands of medicinal plants. Glycosmis pentaphylla (Retz.) A. DC. (Bengali name- Datmajan; Family- Rutaceae) is an unarmed shrub or small tree up to 5.0 meters in height, distributed throughout Bangladesh. It is also available in Sri Lanka, Malaysia, Indonesia, Southern Indo-China, Eastern part of India and in Eastern Australia [1].

In Ayurvedic and other traditional medicinal practices, the plant has some prominent success for treating fever, inflammation and rheumatism in addition to treat bilious complaints, cough, worms, jaundice, anemia, etc. [2,3]. The leaf of this plant was also reported to have anti-inflammatory activity [4]. The stem has a popular use in Bangladesh as a brush for cleaning teeth [5]. G. pentaphylla has been reported as a rich source of alkaloids, terpenoids, flavonoids, naphthoquinone, etc. [6-12].
The one noticeable thing of this plant is that it can work well to manage inflammation and pain as discussed earlier. So, there might be some major responsible secondary metabolites to inhibit cyclooxygenase (COX-2) enzyme, which is liable to produce prostaglandins leading to pain and inflammation. With this view, as part of our ongoing studies on medicinal plants of Bangladesh [13,14], we investigated the leaf extract of G. pentaphylla to isolate some major secondary metabolites. Later isolated compounds were subjected to docking with COX-2 to screen out the major compound(s) responsible for reducing pain and inflammation.

\section{EXPERIMENTAL}

Collection, extraction and isolation: Leaves of Glycosmis pentaphylla were collected from Chittagong, Bangladesh in September 2017. The plant was taxonomically identified at Bangladesh National Herbarium, Dhaka, where a voucher specimen has been deposited, Accession Number DACB-

This is an open access journal, and articles are distributed under the terms of the Creative Commons Attribution-NonCommercial-ShareAlike 4.0 (CC BY-NC-SA 4.0) International License which allows readers to freely read, download, copy, distribute, print, search, or link to the full texts of its articles and to use them for any other lawful non-commercial purpose as long as the original source is duly acknowledged. 
35914. The leaves were first sun dried and then ground into a coarse powder using a grinding machine. The powdered leaf $(1 \mathrm{~kg})$ was soaked in $3 \mathrm{~L}$ methanol for 15 days and then filtered through a cotton plug followed by Whatman filter paper number 1 . The extract was concentrated with a rotary evaporator. A portion $(7 \mathrm{~g})$ of the concentrated methanol extract was partitioned using the modified Kupchan partitioning protocol [15] into petroleum ether (2.3 g), dichloromethane (1.8 g), ethyl acetate $(1.2 \mathrm{~g})$ and aqueous $(1.5 \mathrm{~g})$ soluble materials.

The petroleum ether and dichloromethane soluble partitionates were subjected to size exclusion chromatography using lipophilic sephadex (LH-20) with petroleum ether-dichloromethane-methanol in a ratio of 2:5:1 as a solvent and a total of 40 fractions were collected. On the basis of their TLC behaviour, fractions $6,10,15,17$ and 20 were subjected to preparative thin layer chromatography (PTLC) over silica gel (Kiselgel $\mathrm{F}_{254}$ ) using a solvent system comprising of 3, 5, 10, 20 and 30 $\%$ ethyl acetate in toluene respectively. Arborinine (1), vanillic acid (2), 3-hydroxy-4-methoxybenzoic acid (3) were obtained from $10 \%$, benzoic acid (4) from $30 \%, p$-hydroxybenzoic acid (5) from $20 \%$, stigmasterol (6), $\beta$-amyrin (7) and phytol (8) from $5 \%$ and $3 \alpha, 16 \alpha$-dihydroxyolean-12-ene (9) from 3 $\%$ solvent system.

NMR: ${ }^{1} \mathrm{H}$ NMR spectra were acquired on Ultra Shield Bruker 400 NMR instrument, using $\mathrm{CDCl}_{3}$ and the chemical shifts are reported in ppm with respect to TMS. All solvents and reagents are of highest analytical grade.

Arborinine (1): Yellow gum; ${ }^{1} \mathrm{H} \mathrm{NMR}\left(400 \mathrm{MHz}, \mathrm{CDCl}_{3}\right)$ : $\delta 3.92\left(3 \mathrm{H}, \mathrm{s}, \mathrm{N}-\mathrm{CH}_{3}\right), 3.96\left(3 \mathrm{H}, \mathrm{s}, 2-\mathrm{OCH}_{3}\right), 4.00(3 \mathrm{H}, \mathrm{s}, 3-$ $\left.\mathrm{OCH}_{3}\right), 6.25(1 \mathrm{H}, \mathrm{s}, \mathrm{H}-4), 7.27(1 \mathrm{H}, \mathrm{t}, J=8.8 \mathrm{~Hz}, \mathrm{H}-7), 7.49$ $(1 \mathrm{H}$, br. d, $J=8.8 \mathrm{~Hz}, \mathrm{H}-5), 7.71(1 \mathrm{H}, \mathrm{t}, J=8.8 \mathrm{~Hz}, \mathrm{H}-6)$ and $8.42(1 \mathrm{H}$, br. d, $J=8.8,2.0 \mathrm{~Hz}, \mathrm{H}-8)$.

Vanillic acid (2): Colourless mass; ${ }^{1} \mathrm{H}$ NMR $(400 \mathrm{MHz}$, $\left.\mathrm{CDCl}_{3}\right): \delta 3.95\left(3 \mathrm{H}, \mathrm{s}, 3-\mathrm{OCH}_{3}\right), 6.65(1 \mathrm{H}, \mathrm{d}, J=8.2 \mathrm{~Hz}, \mathrm{H}-5)$, $6.99(1 \mathrm{H}$, br. s, H-2), $7.56(1 \mathrm{H}, \mathrm{s}, 4-\mathrm{OH})$ and $7.68(1 \mathrm{H}, \mathrm{d}, J=$ $8.2 \mathrm{~Hz}, \mathrm{H}-6)$.

3-Hydroxy-4-methoxybenzoic acid (3): Colourless gum; ${ }^{1} \mathrm{H}$ NMR $\left(400 \mathrm{MHz}, \mathrm{CDCl}_{3}\right): \delta 3.98\left(3 \mathrm{H}, \mathrm{s}, 4-\mathrm{OCH}_{3}\right), 6.96$ $(1 \mathrm{H}, \mathrm{d}, J=8.0 \mathrm{~Hz}, \mathrm{H}-5), 7.57(1 \mathrm{H}$, br. s, H-2) and $7.68(1 \mathrm{H}, \mathrm{d}$, $J=8.0 \mathrm{~Hz}, \mathrm{H}-6)$.

Benzoic acid (4): Colourless gum; ${ }^{1} \mathrm{H}$ NMR $(400 \mathrm{MHz}$, $\left.\mathrm{CDCl}_{3}\right): \delta 7.47(2 \mathrm{H}, \mathrm{t}, J=8.0 \mathrm{~Hz}, \mathrm{H}-3, \mathrm{H}-5), 7.61(1 \mathrm{H}, \mathrm{t}, J=$ $8.0 \mathrm{~Hz}, \mathrm{H}-4)$ and $8.10(2 \mathrm{H}, \mathrm{d}, J=8.0 \mathrm{~Hz}, \mathrm{H}-2, \mathrm{H}-6)$.

p-Hydroxybenzoic acid (5): Colourless mass; ${ }^{1} \mathrm{H}$ NMR $\left(400 \mathrm{MHz}, \mathrm{CDCl}_{3}\right): \delta 6.81(2 \mathrm{H}, \mathrm{d}, J=8.0 \mathrm{~Hz}, \mathrm{H}-3, \mathrm{H}-5)$ and $7.98(2 \mathrm{H}, \mathrm{d}, J=8.0 \mathrm{~Hz}, \mathrm{H}-2, \mathrm{H}-6)$.

Stigmasterol (6): Colourless crystals; ${ }^{1} \mathrm{H}$ NMR (400 $\left.\mathrm{MHz}, \mathrm{CDCl}_{3}\right): \delta 0.67\left(3 \mathrm{H}, \mathrm{s}, \mathrm{H}_{3}-18\right), 0.80(3 \mathrm{H}, \mathrm{d}, J=7.0 \mathrm{~Hz}$, $\left.\mathrm{H}_{3}-27\right), 0.84\left(3 \mathrm{H}, \mathrm{d}, J=7.0 \mathrm{~Hz}, \mathrm{H}_{3}-26\right), 0.92(3 \mathrm{H}, \mathrm{d}, J=7.0$ $\left.\mathrm{Hz}, \mathrm{H}_{3}-29\right), 1.00$ (3H, s, $\left.\mathrm{H}_{3}-19\right), 1.02\left(3 \mathrm{H}, \mathrm{d}, J=6.4 \mathrm{~Hz}, \mathrm{H}_{3}-\right.$ 21), $3.52(1 \mathrm{H}, \mathrm{m}, \mathrm{H}-3), 5.01(1 \mathrm{H}, \mathrm{dd}, J=12$ and $8 \mathrm{~Hz}, \mathrm{H}-23)$, $5.12(1 \mathrm{H}, \mathrm{dd}, J=12$ and $8 \mathrm{~Hz}, \mathrm{H}-22), 5.34(1 \mathrm{H}, \mathrm{d}, J=7.0 \mathrm{~Hz}$, H-6).

及-Amyrin (7): Colourless mass; ${ }^{1} \mathrm{H}$ NMR $(400 \mathrm{MHz}$, $\left.\mathrm{CDCl}_{3}\right): \delta 0.78\left(3 \mathrm{H}, \mathrm{s}, \mathrm{H}_{3}-24\right), 0.83\left(3 \mathrm{H}, \mathrm{s}, \mathrm{H}_{3}-28\right), 0.85(3 \mathrm{H}$, s, $\left.\mathrm{H}_{3}-29\right), 0.85$ (3H, s, $\left.\mathrm{H}_{3}-30\right), 0.89$ (3H, s, $\left.\mathrm{H}_{3}-23\right), 0.97(3 \mathrm{H}$, s, $\left.\mathrm{H}_{3}-25\right), 0.97$ (3H, s, $\left.\mathrm{H}_{3}-26\right), 1.02\left(3 \mathrm{H}, \mathrm{s}, \mathrm{H}_{3}-27\right), 3.44(1 \mathrm{H}$, $\mathrm{dd}, J=11.0,3.1 \mathrm{~Hz}, \mathrm{H}-3)$ and $5.23(1 \mathrm{H}, \mathrm{t}, J=3.5 \mathrm{~Hz}, \mathrm{H}-12)$.
Phytol (8): Colourless mass; ${ }^{1} \mathrm{H} \mathrm{NMR}\left(400 \mathrm{MHz}, \mathrm{CDCl}_{3}\right)$ : $\delta 0.83\left(6 \mathrm{H}, \mathrm{d}, J=6.8 \mathrm{~Hz}, 7-\mathrm{CH}_{3}, 11-\mathrm{CH}_{3}\right), 0.85(3 \mathrm{H}, \mathrm{d}, J=6.8$ $\left.\mathrm{Hz}, 15-\mathrm{CH}_{3}\right), 1.66\left(3 \mathrm{H}, \mathrm{s}, 3-\mathrm{CH}_{3}\right), 1.66(1 \mathrm{H}, \mathrm{m}, \mathrm{H}-7), 1.66(1 \mathrm{H}$, m, H-11), $1.66(1 \mathrm{H}, \mathrm{m}, \mathrm{H}-15), 1.98(1 \mathrm{H}, \mathrm{t}, J=7.0 \mathrm{~Hz}, \mathrm{H}-4)$, $4.14(1 \mathrm{H}, \mathrm{d}, J=6.8 \mathrm{~Hz}, \mathrm{H}-1)$ and $5.40(1 \mathrm{H}, \mathrm{t}, J=6.8 \mathrm{~Hz}, \mathrm{H}-2)$.

3 $\alpha, 16 \alpha$-Dihydroxyolean-12-ene (9): Colourless gum; ${ }^{1} \mathrm{H}$ NMR $\left(400 \mathrm{MHz}, \mathrm{CDCl}_{3}\right): \delta 0.75\left(3 \mathrm{H}, \mathrm{s}, 28-\mathrm{CH}_{3}\right), 0.76(3 \mathrm{H}, \mathrm{s}$, $\left.24-\mathrm{CH}_{3}\right), 0.81\left(3 \mathrm{H}, \mathrm{s}, 29-\mathrm{CH}_{3}\right), 0.87\left(3 \mathrm{H}, \mathrm{s}, 30-\mathrm{CH}_{3}\right), 0.95$ $\left(3 \mathrm{H}, \mathrm{s}, 23-\mathrm{CH}_{3}\right), 1.04\left(3 \mathrm{H}, \mathrm{s}, 26-\mathrm{CH}_{3}\right), 1.05\left(3 \mathrm{H}, \mathrm{s}, 25-\mathrm{CH}_{3}\right)$, $1.24\left(3 \mathrm{H}, \mathrm{s}, 27-\mathrm{CH}_{3}\right), 3.42(1 \mathrm{H}, \mathrm{s}, \mathrm{H}-3), 4.65(1 \mathrm{H}$, br. s, H-16) and $5.25(1 \mathrm{H}, \mathrm{t}, J=3.2 \mathrm{~Hz}, \mathrm{H}-12)$.

Preparation of target COX-2 X-ray structure: The crystal structure of mammalian COX-2 complexed with celecoxib (PDB code: 3LN1) [16] was selected. Water molecules, ligands and chain B, C and D of 3LN1 were removed and polar hydrogen atoms were added to the proteins using PyMOL (Version 1.7.4.4, Schrödinger). Energy minimization was performed by applying YASARA force field level of theory in YASARA Energy Minimization Server (http://www.yasara.org/ minimizationserver.htm).

Preparation of ligands: The initial structure of celecoxib, arborinine (1), vanillic acid (2), 3-hydroxy-4-methoxybenzoic acid (3), benzoic acid (4), $p$-hydroxybenzoic acid (5), stigmasterol (6), $\beta$-amyrin (7), phytol (8) and $3 \alpha, 16 \alpha$-dihydroxyolean-12-ene (9) were obtained from PubChem (https:// pubchem.ncbi.nlm.nih.gov/search/). Molecular geometry was optimized with MMFF94 level of theory using in Open Babel [17]. The optimized structure of ligands was then converted to pdbqt (Protein Data Bank, Partial Charge (Q) \& Atom Type (T)) format for docking study.

Protein-ligand docking: The docking of target protein with the ligand was conducted using AutoDock vina [18]. The docking was performed using a box of volume $(25.00 \times 25.00$ $\times 25.00) \AA^{3}$ with a center of $(34.913,-28.985,-9.511)$. Ligands with lowest binding affinity and promising binding pose were chosen as the best conformation. The interactions of different residues of COX-2 with ligands were analyzed by PyMOL [19]. Before screening the ligands, the docking protocol was validated by re-docking celecoxib into the binding pocket of 3LN1 to get the docked pose displaying the root mean square deviation (RMSD) less than 1.

\section{RESULTS AND DISCUSSION}

Characterization of isolated compounds: Nine compounds were isolated from the leaf extract through various chromatographic methods. The ${ }^{1} \mathrm{H}$ NMR spectrum $(400 \mathrm{MHz}$, $\mathrm{CDCl}_{3}$ ) of compound 1 revealed proton signals characteristic of a polycyclic acridone-type alkaloid, where two of the three hydroxyl groups were methylated (-OMe). The spectrum displayed a highly characteristic ABCD spin system with four aromatic proton resonances at $\delta 7.49,7.71,7.27$ and 8.42, which could be ascribed to four adjacent protons at C-5, C-6, C-7 and $\mathrm{C}-8$, respectively. The sharp singlet at $\delta 6.25$ was attributable to the aromatic proton at C-4 of ring A. On the other hand, the singlet of three proton intensity at $\delta 3.92$ could be assigned to $\mathrm{N}-\mathrm{CH}_{3}$. Two sharp singlets, each integrating for three protons, at $\delta 3.96$ and 4.00 were assigned to two methoxyl groups. Thus, the structure of compound $\mathbf{1}$ was solved as arbo- 
rinine which was further supported by comparing its ${ }^{1} \mathrm{H}$ NMR spectral data with reported values [20] as well as by co-TLC with an authentic sample.

The ${ }^{1} \mathrm{H}$ NMR spectrum ( $400 \mathrm{MHz}, \mathrm{CDCl}_{3}$ ) of compound 2 exhibited a broad singlet at $\delta 6.99$ assignable to $\mathrm{H}-2$. Two doublets $(J=8.2 \mathrm{~Hz})$ centered at $\delta 6.95$ and 7.68 could be ascribed to $\mathrm{H}-5$ and $\mathrm{H}-6$, respectively. A sharp singlet at $\delta$ 3.95 was attributed to the methoxy group at C-3. It also showed a singlet at $\delta 7.56$, which suggested a hydroxyl proton at C-4. On the basis of the above spectral data, compound 2 was characterized as vanillic acid (4-hydroxy-3-methoxybenzoic acid) which has been confirmed by comparing its spectral data with reported values [21].

The ${ }^{1} \mathrm{H}$ NMR spectrum $\left(400 \mathrm{MHz}, \mathrm{CDCl}_{3}\right)$ of compound 3 displayed a broad singlet at $\delta 7.57$, which could be assigned to $\mathrm{H}-2$. Two doublets $(J=8.0 \mathrm{~Hz})$, centered at $\delta 6.96$ and 7.68 could be ascribed to $\mathrm{H}-5$ and $\mathrm{H}-6$, respectively. The sharp singlet of three proton intensity at $\delta 3.98$ was attributed to the methoxy group at C-4. By comparing the above spectral features with those of the 3-hydroxy-4-methoxybenzoic acid [22], compound 3 was characterized.

The ${ }^{1} \mathrm{H}$ NMR spectrum ( $400 \mathrm{MHz}, \mathrm{CDCl}_{3}$ ) of compound 4 displayed a doublet $(J=8.0 \mathrm{~Hz})$ for two protons at $\delta 8.10$ that could be assigned to H-2 and H-6 having the same environment. A triplet $(J=8.0 \mathrm{~Hz})$ for two protons at $\delta 7.47$ could similarly be ascribed to $\mathrm{H}-3$ and $\mathrm{H}-5$. On the other hand, another triplet of one proton intensity resonating at $\delta 7.61(J=8.0 \mathrm{~Hz})$ was characteristic of $\mathrm{H}-4$. Thus the identity of compound $\mathbf{4}$ as benzoic acid was confirmed by comparing its spectral data with previously reported values [23].

The ${ }^{1} \mathrm{H}$ NMR spectrum $\left(400 \mathrm{MHz}, \mathrm{CDCl}_{3}\right.$ ) of compound 5 showed doublet of two proton intensity at $\delta 7.98(J=8.0$ $\mathrm{Hz}$ ), which could be ascribed to $\mathrm{H}-2$ and $\mathrm{H}-6$ having the same environment. Another doublet with $J$ value $8.0 \mathrm{~Hz}$ at $\delta 6.81$ could be assigned to $\mathrm{H}-3$ and $\mathrm{H}-5$. Therefore, compound 5 was characterized as $p$-hydroxybenzoic acid [24,25].

The ${ }^{1} \mathrm{H}$ NMR (400 MHz, $\mathrm{CDCl}_{3}$ ) spectrum of compound 6 displayed a one proton multiplet at $\delta 3.52$, the position and multiplicity of which was indicative to $\mathrm{H}-3$ of a steroidal nucleus. The typical olefinic H-6 of the steroidal skeleton was evident as a doublet $(J=7.0 \mathrm{~Hz})$ at $\delta 5.34$ that integrated for one proton. It also showed olefinic protons at $\delta 5.12$ and $5.01(\mathrm{H}-22$ and $\mathrm{H}-23)$. The spectrum also revealed signals at $\delta 0.67$ and $\delta 1.00$ (3H each) assignable to two tertiary methyl groups at $\mathrm{C}-13$ $\left(\mathrm{H}_{3}-18\right)$ and $\mathrm{C}-10\left(\mathrm{H}_{3}-19\right)$, respectively. Two doublets $(J=7.0$ $\mathrm{Hz})$ centered at $\delta 0.84\left(\mathrm{H}_{3}-26\right)$ and $0.85\left(\mathrm{H}_{3}-27\right)$ which could be ascribed to the methyl groups at $\mathrm{C}-25$. The doublets $(J=$ $6.4 \mathrm{~Hz})$ at $\delta 1.02\left(\mathrm{H}_{3}-21\right)$ was assignable to the methyl group at C-20. On the other hand, the doublet $(J=7.0 \mathrm{~Hz})$ of three proton intensity at $\delta 0.92\left(\mathrm{H}_{3}-29\right)$ could be ascribed to the primary methyl attached to C-28. Two singlets of three proton intensity each at $\delta 0.67$ and 1.00 could be assigned to the primary methyl group attached to $\mathrm{C}-18$ and $\mathrm{C}-19$, respectively. Co-TLC of the compound with previously isolated authentic stigmasterol, confirmed the identity of compound $\mathbf{6}$ as stigmasterol which has previously been reported from G. pentaphylla [26].

The ${ }^{1} \mathrm{H}$ NMR spectrum $\left(400 \mathrm{MHz}, \mathrm{CDCl}_{3}\right.$ ) of compound 7 displayed the presence of eight methyl singlets at $\delta 0.89$,
$0.78,0.97,0.97,1.02,0.83,0.85$ and 0.85 for Me-23, Me-24, Me-25, Me-26, Me-27, Me-28, Me-29 and Me-30, a characteristic triplet $(J=3.5 \mathrm{~Hz})$ at $\delta 5.23$ for $\mathrm{H}-12$ and a double doublet $(J=11.0,3.1 \mathrm{~Hz})$ of one proton intensity at $\delta 3.44$ was typical for the oxymethine proton $(\mathrm{H}-3)$ of the pentacyclic triterpene. On this basis, compound 7 was characterized as $\beta$-amyrin, the identity of which was confirmed by comparing its spectral data with published values [27] as well as co-TLC with authentic sample.

The ${ }^{1} \mathrm{H}$ NMR spectrum (400 MHz, $\mathrm{CDCl}_{3}$ ) of compound 8 exhibited a doublet of two proton intensity at $\delta 4.14(J=6.8$ $\mathrm{Hz}$ ), which could be assigned to H-1. A broad triplet for one proton observed at $\delta 5.40$, was attributed to the olefinic methine $(=\mathrm{CH}-)$. The triplet at $\delta 1.98$ of two proton intensity was ascribed to $\mathrm{H}-4$. A multiplet at $\delta 1.07$ indicated the presence of two protons at $\mathrm{H}-7$ and $\mathrm{H}-11$. The proton attached to the terminal methyls at $\mathrm{C}-15$ were observed as a multiplet at $\delta$ 1.66. A doublet at $\delta 0.83$ for another six methyl protons was assigned to the positions at $\mathrm{C}-7$ and $\mathrm{C}-11$. In addition, a doublet at $\delta 0.85(J=6.8 \mathrm{~Hz})$ for six methyl protons was attributed to two methyl groups attached to $\mathrm{C}-15$. The above spectral features were comparable to those of phytol [28].

The ${ }^{1} \mathrm{H}$ NMR spectrum $\left(400 \mathrm{MHz}, \mathrm{CDCl}_{3}\right.$ ) of compound 9 showed an olefinic proton signal at $\delta 5.25(\mathrm{t}, J=3.2 \mathrm{~Hz})$. The chemical shift of this proton suggested its placement at $\mathrm{C}-12$. The broad singlet at $\delta 3.42$ could be assigned to an oxymethine proton at $\mathrm{C}-3$. The absence of any visible coupling suggested that the proton was at $\beta$-position and thus $\mathrm{OH}-3$ was $\alpha$-oriented. A characteristic broad singlet of one proton intensity at $\delta 4.65$ revealed the presence of another oxymethine proton at $\mathrm{C}-16$ of the triterpenoid skeleton. Here, the oxygenated substituent (-OH) at $\mathrm{C}-16$ was $\alpha$-oriented. The ${ }^{1} \mathrm{H}$ NMR spectrum also displayed eight methyl group resonances as singlets at $\delta 0.95,0.76,1.05,1.04,1.24,0.75,0.81$ and 0.87 . The above spectral features are in close agreement to those observed for $3 \alpha, 16 \beta$-dihydroxyolean-12-ene [29] and thus, compound 9 was characterized as $3 \alpha, 16 \alpha$-dihydroxyolean12-ene.

Molecular docking study: G. pentaphylla was reported earlier to have anti-inflammatory and analgesic potentials. In order to determine the principal bioactive molecule(s), the isolated compounds were subjected to docking study with COX-2. It revealed that among all the ligands, arborinine and phytol bind at the binding pocket of COX-2 with strong binding affinity (i.e. $-8.2 \mathrm{Kcal} / \mathrm{mol}$ and $-7.5 \mathrm{Kcal} / \mathrm{mol}$, respectively). The structural analysis showed that arborinine forms hydrogen bonding with SER339 and MET508 (Fig. 1A). The binding of ligand at the binding pocket is further stabilized by van der Waals interactions with Val102, Val335, Leu338, Tyr341, Phe367, Leu370, Tyr371, Trp373, Phe504, Val509, Ala513, Ser516 and Leu517. The binding position of arborinine can be considered very close to that of celcecoxib, a standard COX2 inhibitor drug (Fig. 1C). The structural analysis of COX-2phytol complex revealed that phytol makes one hydrogen bonding with Ser339 and interact with the side chain of Val102, Val335, Leu338, Trp341, Leu345, Trp373, Ala502, Phe504, Met508, Val509, Ala513, Ser516 and Leu517 through van der Waals interactions (Fig. 1B). Phytol is positioned within 4.0 


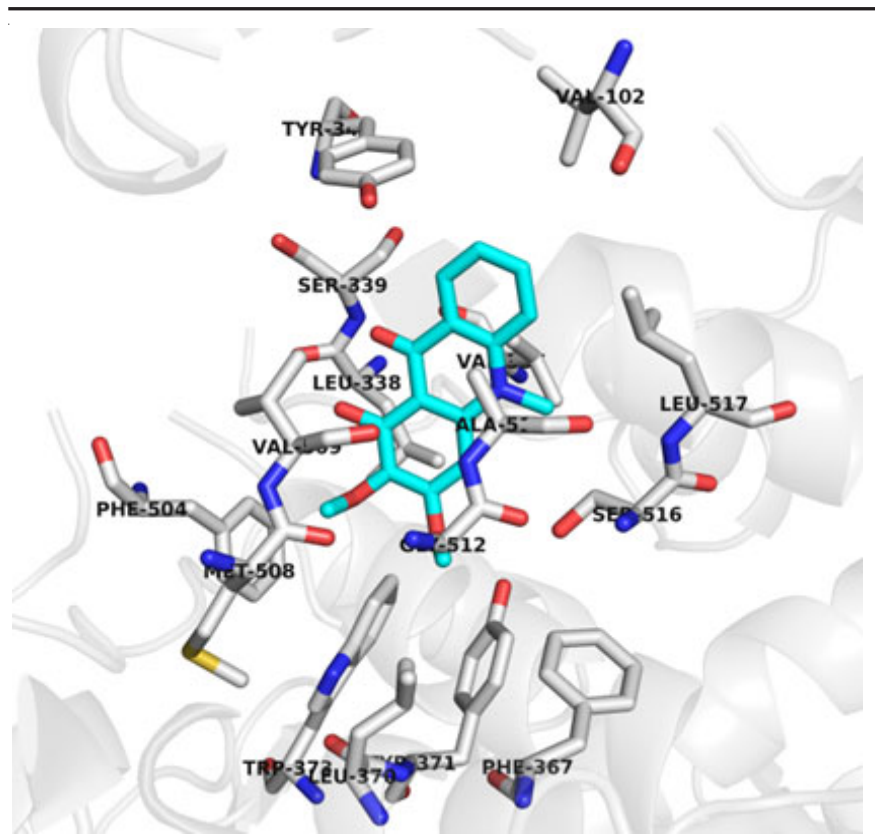

(A)

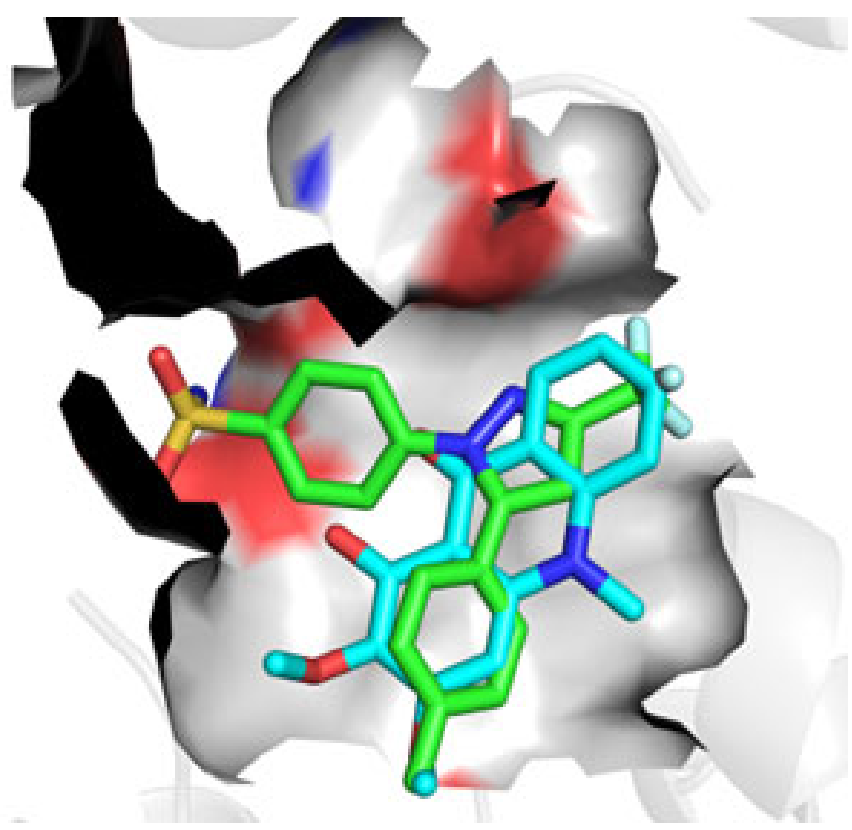

(C)

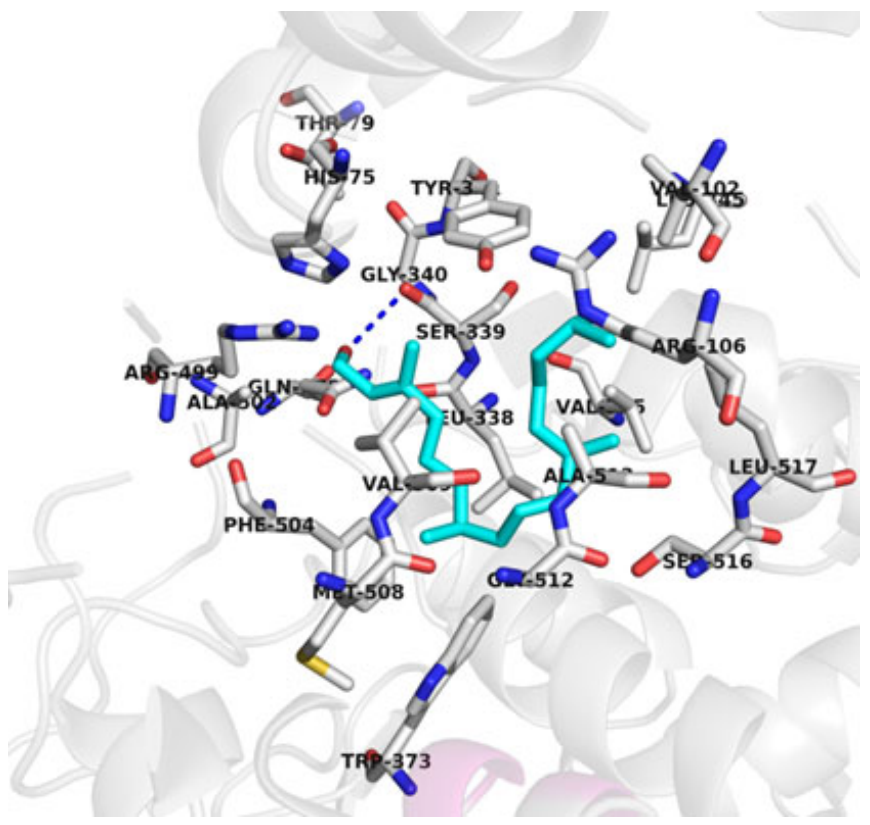

(B)

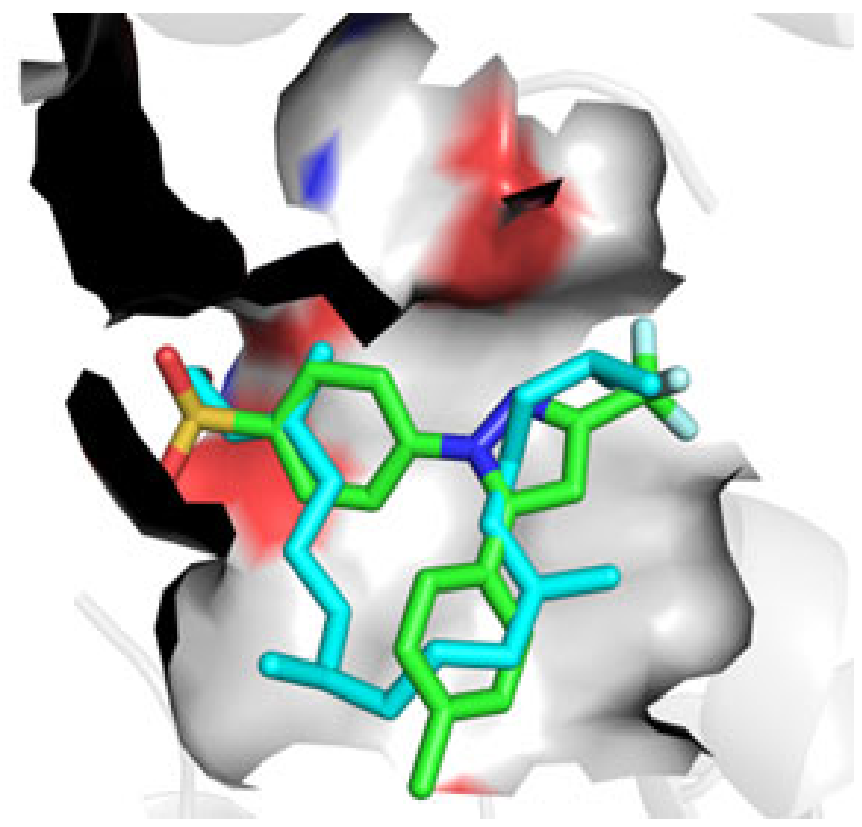

(D)

Fig. 1. Arborinine (cyan) (A) and phytol (cyan) (B) interacting with different residues (white) of COX-2 at the binding pocket. Blue dash indicates hydrogen bonding. Superimposed binding position of celecoxib (green) \& arborinine (cyan) (C) and celecoxib (green) \& phytol (cyan) (D) at the active site of COX-2

$\AA$ from the Thr79, Gly340, Gln178, Arg499 and Gly512 at the binding pocket. As phytol can insert a functional group into the side pocket of COX-2 like celecoxib, it may exert its analgesic action by selectively inhibiting COX-2 enzyme (Fig. 1D).

\section{Conclusion}

The isolation work on leaves of G. pentaphylla furnished nine compounds, arborinine (1), vanillic acid (2), 3-hydroxy4-methoxybenzoic acid (3), benzoic acid (4), $p$-hydroxybenzoic acid (5), stigmasterol (6), $\beta$-amyrin (7), phytol (8) and $3 \alpha, 16 \alpha$ dihydroxyolean-12-ene (9). Among these, in silico docking studies identified arborinine and phytol as bioactive metabolites having COX-2 inhibitory potentials, which might explain the use of the leaves of this plant as analgesic and anti-inflammatory drugs.

\section{CONFLICT OF INTEREST}

The authors declare that there is no conflict of interests regarding the publication of this article.

\section{REFERENCES}

1. M.S. Pramanik, M.Y. Akter, A.E. Ekram, H. Islam, A.R. Khan and N. Islam, J. Life Earth Sci., 3, 33 (2009); https://doi.org/10.3329/jles.v3i0.7443. 
2. P.S. Sreejith, R.J. Praseeja and V.V. Asha, J. Pharm. Res., 5, 2723 (2012).

3. S.S. Nayak, R. Jain and A.K. Sahoo, Pharm. Biol., 49, 111 (2011); https://doi.org/10.3109/13880209.2010.501084.

4. P. Ansari and S. Azam, Am. J. Biomed. Res., 3, 6 (2015).

5. M.Z. Uddin, M.A. Hassan and M. Sultana, Bangladesh J. Plant Taxon., 13, 63 (2006); https://doi.org/10.3329/bjpt.v13i1.596.

6. I. Ahmed, R. Islam, M.A.A. Sikder, M.R. Haque, M.A. Al Mansur and M.A. Rashid, Dhaka Univ. J. Pharm. Sci., 13, 115 (2014); https://doi.org/10.3329/dujps.v13i2.21887.

7. L. Chen, J.F. Xu and L.C. Sun, Zhong Yao Cai, 39, 90 (2016).

8. Y. Chen, C. Tang, Y. Wu, S. Mo, S. Wang, G. Yang and Z. Mei, Org. Biomol. Chem., 13, 6773 (2015); https://doi.org/10.1039/C5OB00695C.

9. E.L. Tian, Y.Y. Cui, G.Z. Yang, Z.N. Mei and Y. Chen, J. Asian Nat. Prod. Res., 16, 1119 (2014); https://doi.org/10.1080/10286020.2014.951924.

10. J. Wang, Y. Di, X. Yang, S. Li, Y. Wang and X. Hao, Phytochemistry, 67, 486 (2006); https://doi.org/10.1016/i.phytochem.2005.11.025.

11. J. Wang, X. Yang, Y. Di, Y. Wang, Y. Shen and X. Hao, J. Nat. Prod., 69, 778 (2006); https://doi.org/10.1021/np060001q.

12. Y. Wu, X. Hu, G.Z. Yang, Z.N. Mei and Y. Chen, J. Asian Nat. Prod. Res., 14, 738 (2012); https://doi.org/10.1080/10286020.2012.688745.

13. M. Ibrahim, M.A. Hossain, M.S. Shajib and M.A. Rashid, Dhaka Univ. J. Pharm. Sci., 17, 73 (2018); https://doi.org/10.3329/duips.v17i1.37121.

14. M.S. Shajib, B.K. Datta, M.H. Sohrab, M.A. Rashid, L. Nahar and S.D. Sarker, Rec. Nat. Prod., 11, 568 (2017); https://doi.org/10.25135/rnp.73.17.04.080.

15. B.C. VanWagenen, R. Larsen, J.H. Cardellina, D. Randazzo, Z.C. Lidert and C. Swithenbank, J. Org. Chem., 58, 335 (1993); https://doi.org/10.1021/jo00054a013.
16. J.L. Wang, D. Limburg, M.J. Graneto, J. Springer, J.R.B. Hamper, S. Liao, J.L. Pawlitz, R.G. Kurumbail, T. Maziasz, J.J. Talley, J.R. Kiefer and J. Carter, Bioorg. Med. Chem. Lett., 20, 7159 (2010); https://doi.org/10.1016/j.bmcl.2010.07.054.

17. N.M. O'Boyle, M. Banck, C.A. James, C. Morley, T. Vandermeersch and G.R. Hutchison, J. Cheminform., 3, 33 (2011); https://doi.org/10.1186/1758-2946-3-33.

18. O. Trott and A.J. Olson, J. Comput. Chem., 31, 455 (2010); https://doi.org/10.1002/jcc. 21334

19. W.L. DeLano, The PyMOL Molecular Graphics System, DeLano Scientific: San Carlos, USA, p. 452 (2002).

20. M. Rahmani, R.M. Serang, N.M. Hashim, M.A.S. Gwendoline, A.M. Ali and H.B.M. Ismail, Sains Malays., 39, 445 (2010).

21. K. Bao, A. Fan, Y. Dai, L. Zhang, W. Zhang, M. Cheng and X. Yao, Org. Biomol. Chem., 7, 5084 (2009); https://doi.org/10.1039/b916969e.

22. S. Kobayashi, T. Ozawa and H. Imagawa, Agric. Biol. Chem., 46, 845 (1982); https://doi.org/10.1271/bbb1961.46.845.

23. W. Yang, G.-Z. Gou, Y. Wang and W.-F. Fu, RSC Adv., 3, 6334 (2013); https://doi.org/10.1039/C3RA00046J.

24. S. Sukari and I.M. Said, Malays. J. Anal. Sci., 17, 276 (2013).

25. J.-Y. Cho, J.-H. Moon, K.-Y. Seong and K.-H. Park, Biosci. Biotechnol. Biochem., 62, 2273 (1998); https://doi.org/10.1271/bbb.62.2273.

26. V.S.P. Chaturvedula and I. Prakash, Int. Curr. Pharm. J., 1, 239 (2012); https://doi.org/10.3329/icpj.v1i9.11613.

27. T. Kushiro, M. Shibuya and Y. Ebizuka, Eur. J. Biochem., 256, 238 (1998); https://doi.org/10.1046/j.1432-1327.1998.2560238.x.

28. N.D. Phatangare, K.K. Deshmukh, V.D. Murade, G.J. Hase and T.R. Gaje, Int. J. Pharmacog. Phytochem. Res., 9, 864 (2017). https://doi.org/10.25258/phyto.v9i6.8192.

29. M. da P. Lima, P.A.C. Braga, M.L. Macedo, M.F.G.F. Silva, A.G. Ferreira, J.B. Fernandes and P.C. Vieira, J. Braz. Chem. Soc., 15, 385 (2004); https://doi.org/10.1590/S0103-50532004000300008. 